\title{
Resident Perceptions of Mixed-Use Development in Hout Bay, CaPe Town
}

M J Scheepers and J Z Bloom

Department of Business Management, University of Stellenbosch

\begin{abstract}
Urban renewal and development is an important strategy in the South African government's plans to combat poverty and transform the country's economy. The aim of this study was to investigate the perceptions and attitudes of residents (the local community) towards a mixed-use development in Hout Bay, Cape Town. An exploratory factor analysis was used to reduce 13 usable variables to four factors, labelled as macro-, micro-, location specific-, and infrastructure and superstructure factors. The findings based on the four factors suggest that significant differences exist in the perceptions of development between different socio-economic groups within the community. Regardless of the socio-economic background of residents, they agreed that development should blend in with existing architecture and the character of the area.
\end{abstract}

JEL R58

\section{1}

\section{Introduction and background}

Urban renewal and rural development is an important strategy in the South African government's plans to combat poverty, transform the second economy, and integrate the first and second economies. Some of the positive impacts of development are increased job opportunities, economic growth, increased wealth, improved facilities, wider access to consumer goods and increased tax revenues.

On the other hand, criticisms have also been levelled against development. Development is perceived to be the main culprit of damage caused to the environment (Parsa \& Farshchi, 1996: 6). Residents of developing areas complain that the environment and character of their towns are being lost due to incompatible development and associated environmental changes (Green, 1999: 311, Gubb, 2003). Dominant research themes related to development in the European Union, the United Kingdom and the United States are primarily environmental, social and community-driven issues.

The purpose of this study is to investigate the perceptions and attitudes of residents (the local community) towards a mixed-use development in Hout Bay, Cape Town. The study aims to address the following issues: whether or not the perceptions of residents regarding urban development can be reduced to several key factors, and whether or not socio-economic groups within a local area differ with regard to their views concerning development. Taking into account the history of South Africa and the distorted spatial economies of towns and cities that stem from segregationist apartheid policies, the use of the findings of the research to analyse the latter questions is particularly interesting (Pillay \& Du Toit, 2004).

This research is based on a case study of mixed-use development in Hout Bay. In an attempt to address these issues, this paper will first provide a background and describe the proposed development for Hout Bay; thereafter, aspects of macro and micro impact are 
discussed, followed by the research methodology, statistical analysis and results, and the interpretation of the findings. Additional avenues for research are also proposed.

The importance of the study could be attributed to the following: Firstly, the contribution that urban development can make towards developing South Africa's second economy. Secondly, that most international studies regarding property focus on the impact of development from an economic or investment perspective, and generally ignore the social consequences and perceptions of residents towards development. Thirdly, that limited research exists into the perceptions of residents regarding development, particularly in South Africa.

Urban development can make an important contribution to economic growth and wealth creation in South Africa. The Growth and Development Summit, convened in 2003, focused the agenda on the need for growth and development in and of South Africa. Development is seen as an important strategy to push back the frontiers of poverty and underdevelopment (Mbeki, 2003). Although South Africa is able to boast one of the most developed first economies in Africa, the second economy is under-developed.

The first economy can be described as modern, produces the bulk of the country's wealth and is integrated within the global economy. In contrast, the second economy can be described as being under-developed, isolated from the first and global economies, comprising a large percentage of people including the urban and rural poor, and making a limited contribution to the country's wealth. For example, hawkers, who form part of the second economy, purchase most of their inventory (stock) in the first economy and resell it to the second economy. President Mbeki (2003) has repeatedly indicated that one of the major challenges to transform the second economy is rural upliftment and the development of land as part of urban renewal programmes undertaken by municipalities.

\section{2}

\section{Literature overview}

A broad overview of the literature (Hallsworth \& Johnson, 2001; Guy, 1996; Brammer \& Tomasik, 1995; Tausik, 1999; O’Neil \& Delmerico, 1995; Ircha, 1982; Callegari \& Vallega, 2002; Manzo, 2003; Green, 1999; Ho, 1997; Alzubaidi et al., 1997; Jones \& Hillier, 2002; Amit-Cohen, forthcoming), suggests that the proposed development would impact the lives of residents at different economic, environmental, socio-cultural and community levels. It also appears that most of the authors listed above focus on property development, retail development, leisure development and developments within coastal areas, which is aligned with the mixed-use development considered in this study. The scope of the development included a commercial centre, a petrol station, and sporting facilities together with a riding school.

It is apparent from an assessment of the literature that the impact of property development is generally approached from an economic or financial viability (investment) perspective. For instance, Simons (1991) and Brammer and Tomasik (1995) focus on the economic impact of retail development. Other approaches to development focus on the sustainability of development (Callegari \& Vallego, 2002; Bowen \& Riley, 2003; Mokhtar, Aziz \& Aziz, 2003; Coastal Futures, 2000) and the impact of development on the environment (Parsa \& Farshchi, 1996; Kaltenborn, 1998).

It appears that human or social consequences are seldom considered at the same level of importance when compared to the impact of development on the economy (Corgel, Ling \& Smith, 2001; Schilling, 2002) or natural resources (Kaltenborn, 1998: 170). Indications are that more emphasis is being placed on the social issues and residents' perceptions and attitudes towards development (Ho, 1997: 94). Despite the increasing emphasis on community perceptions of development, limited empirical research has been undertaken to explore this phenomenon. 
Impacts such as population growth, human pressure and climate change have contributed towards the worldwide interest in the management of urban development near coastlines (Callegari \& Vallego, 2002; Bowen \& Riley, 2003; Taussik, 1999). The nature and scope of development-related impacts vary from location to location, but essentially there are a number which are common to all locations. It is possible to categorise impacts in terms of those that a community would have limited or no control over, and developmentspecific impact, which could be mitigated prior to the start of a development. For the purposes of assessing impacts, a classification is used which reflects what may be termed macro and micro impacts.

\subsection{Macro impacts}

According to a 1998 report of the European Union Expert Group on the Environment, the sustainability agenda places new emphasis on the inter-relationships between the physical environment and the human and economic systems. They acknowledged that there is a capacity beyond which the environment cannot sustain activity levels (O'Regan et al., 2002: 451). The economic, environmental and sociocultural processes, which are involved in urban development, are considered as the macro points of departure.

\subsubsection{Economic impacts}

Development entails various costs and benefits for any community. Well-known economic benefits include economic growth (due to the multiplier effect) (Hallsworth \& Johnson, 2001: 464), job-creation (Guy, 1996: 229) and improved infrastructure (Jones \& Hillier, 2002). These can contribute to a higher standard of living for people living in these areas. Other economic benefits of commercial development include wider access to consumer goods, increased tax revenues, contributions to permanent employment and an increase in personal per capita income (Arnold \& Luthra, 2000: 146; Brammer \& Tomasik, 1995: 32). Residents of Hout Bay could possibly benefit from the mixed-use development in several ways.
However, macro-economic development challenges the status quo and often results in resistance to change among communities. Hallsworth and Johnson (2001: 467-8) found that although community protest is a logical response in the development phase of new projects, assessments appear less severe postopening. Further negative economic perceptions allude to property owners being affected by the devaluation of neighbouring residential property (Taussik, 1999: 754; O’Neil \& Delmerico, 1995: 88). In addition, trade in more established areas could decline and lead to reduced commercial investment in 'older' developed areas as well as neighbouring towns (Hallsworth \& Johnson, 2001: 467). Several authors (Arnold \& Luthra, 2000: 144; Vance \& Scott, 1994; Ircha, 1982) also provide evidence that national and international developers can impoverish an area due to the repatriation of capital and dividends. Developments do not only have an impact on the economy, but also on the environment.

\subsubsection{Environmental impacts}

Although development is inevitable, due to an increase in human population, ecological, socio-economic and cultural diversity should be maintained (Callegari \& Vallego, 2002: 231). Some environmental costs of property development are deterioration in the health of residents, local pollution and related environmental problems (Taussik, 1999: 752). Other externalities of development include increases in traffic, waste and noise (Hallsworth \& Johnson, 2001: 465). Thus it can be argued that all development needs to be sustainable within an environmental context (Callegari \& Vallega, 2002: 230). Sustainable development needs to maximise permanent employment opportunities by considering the environmental, socio-cultural and community impact (Gubb, 2003; Perrings \& Ansuategi, 2000: 36).

\subsubsection{Socio-cultural impacts}

Development has an impact on the quality of life of communities, psychological and emotional attachment to place and patterns of social interaction (Manzo, 2003). These changes result in changes in different levels of 
demand for infrastructure, and issues of accessibility and proximity of residents to developments (Fife, 2003: 62). Quality of life and changing patterns of social interaction are viewed as macro socio-cultural impacts, while changes to infrastructure and issues such as accessibility and proximity of residents to developments are addressed as micro impacts.

Quality of life depends on the community's subjective perception of its own health and the degree and quality of social and community interaction, as well as physical and psychological well-being. A mixed-use development such as the multi-leisure and commercial complex assessed in this study offers enhanced leisure opportunities for patrons (Jones \& Hillier, 2002: 427). However, Manzo (2003: 48-9) suggests that people often have emotional relationships with places, and as such, these can be a driving behavioural force.

Oelofse and Dodson (1997: 91-8) support the view that people's emotional relationships also exist within a larger socio-political milieu. They conducted a descriptive study where formal residents' perceptions (in Hout Bay) to the development of an informal settlement were investigated. Although not directly applicable to this study, residents perceived the impact of the informal settlement as a threat to security, property prices, environmental quality, pollution, congestion, health conditions and their quality of life. Green (1999: 311) warns against this particular phenomenon by postulating that degradation and loss of town character is becoming more apparent in many coastal towns as the incremental effects of poorly controlled change in the built environment occur at an increasing rate.

Residents in affected communities can become alienated from their familiar local surroundings as a consequence of the loss of town character. This in turn may have a negative impact on the general sense of well-being among residents. Developers should conserve and manage environmental features so that the positive and unique character of a town can be reinforced. In this manner some of the negative psychological effects town growth can have on communities can be reduced (Green, 1999: 311). These dangers are also inherent in the proposed development investigated as part of this study.

Developments also lead to changes in patterns of social interaction such as pleasant shopping experiences. New shopping centres in particular offer benefits such as a one-stop shopping experience in an efficient, climate-controlled setting, with extended shopping hours (Hallsworth \& Johnson, 2001: 465; Ho, 1997: 97). The commercial facility which forms part of the mixed-use development would offer convenient shopping opportunities to Hout Bay residents.

On the one hand, the competitive threat posed by new facilities has acted as a stimulus for the refurbishment and revitalisation of some traditional centres (Hallsworth \& Johnson, 2001: 429). On the other hand, the decline in the competitive position of existing centres and their associated problems of environmental degradation has caused considerable concern to traders and public agencies alike (Bromley \& Thomas, 1993: 150). In a limited number of cases, the development of a new facility in close proximity to an existing, weak centre of similar functional status has resulted in the decline of the older centre (Guy, 1996: 230). The case study presented in this article did not specifically focus on investigating quality of life issues. Macro impacts of developments can thus be considered as the integration of economic, environmental and social benefits and costs.

\subsection{Micro impacts}

Micro as opposed to macro impact of development directly affects and possibly changes the patterns of social interaction among members of the community. Issues of accessibility and proximity of residents to developments and the architectural styles used by developers are also highlighted as conduits of change in demand for infrastructure (Fife, 2003: 62).

Development has an influence on the demand for infrastructure of a town. Bromley and Thomas (1993: 150) indicate that a new retail development can deflect traffic from the town centre and contain or even reduce congestion. Conversely, new facilities can generate traffic 
congestion if the issue of traffic circulation is not adequately addressed (Hallsworth \& Johnson, 2001: 430). Especially in the case of mixed-use developments, additional housing leads to increases in population within a town, which also places an added burden on existing infrastructure (Bowen \& Riley, 2003: 9). While the building and construction of new developments are taking place, residents are exposed to construction activity. Several researchers have suggested that development may result in undesired construction activity, increases in traffic, waste, noise and water pollution (Arnold \& Luthra, 2000; Hallsworth \& Johnson, 2001: 465; Ho, 1997: 95).

Issues of convenience, centrality, proximity and accessibility have an influence on the perceptions and extent of change experienced by residents. Developments, such as the opening of a large format retailer, are associated with inherent consumer benefits. These benefits include a wider assortment of goods and stores, lower prices, changes in the job market (job creation and job losses, changes in job quality), a one-stop shopping experience, convenient free parking, extended shopping hours and so forth (Arnold \& Luthra, 2000: 152; Jones \& Hillier, 2002: 429). The mixed-use development assessed in the study also includes a commercial facility which would be accessible to local residents. Residents would not need to travel excessive distances to access these facilities. The increased spending in the local community would also offer further economic benefits and job opportunities.

The proposed development in Hout Bay included sport and recreation components. Jones and Hillier (2002: 429) investigated the impact of multi-leisure complexes on towns. They identified several impacts, such as changing trade patterns and an overall increase in the diversity of leisure, but also potential problems related to an increase in traffic flows, parking problems, entertainment noise, and general disturbance. Consumers perceived the convenience of a location, proximity and centrality to other developments, and accessibility and free parking as important factors (Arnold \& Luthra, 2000: 141; Alzubaidi et al., 1997: 80; Ho, 1997: 98) influencing their overall perceptions and attitudes towards the new development.

As discussed in section 2.3.1, developers also need to account for residents' emotional attachment to place. In order to guard against the alienation of residents, new developments' architecture and design should blend in with the existing surroundings (Amit-Cohen, forthcoming). Environmental features that reinforce a distinctive and positive town character experience should be managed. This is one strategy of alleviating some of the negative psychological effects town growth can have on communities (Green, 1999: 311). Thus new buildings should be vernacular in design and blend in with the architecture of other buildings in the surrounding area.

In the South African context, it appears that limited research has been undertaken to address the social and community perspectives. Oelofse and Dodson (1997) conducted a qualitative study which presents a perceptual analysis of residents' responses to the development of an informal settlement in Hout Bay, Cape Town. The Human Sciences Research Council recently formed an urban renewal unit to conduct cross-disciplinary social research within a focused programme. It is intended that the research should address the 'gap' of knowledge that exists in South Africa with specific reference to urban renewal and development (Pillay \& Du Toit, 2004).

This study investigated certain important impacts identified in the literature. Various statements were formulated to ascertain the perceptions and attitudes of residents in the Hout Bay area. Residents' responses to 15 statements towards mixed-use property development were recorded, together with other supporting information. The 15 statements (section 4.3) refer to the economic, environmental and socio-cultural aspects and specific issues related to the convenience, centrality, accessibility and proximity of land envisaged for mixed-use development.

The empirical findings of this study are intended to support the ongoing research efforts of others and contribute to the knowledge base by assessing differences in residents' perceptions of development from a socio-economic 
perspective. In particular, this study conducted in 2001 focuses on residents' perceptions of a mixed-use development in an ecologically sensitive area.

\section{3}

\section{Nature of communities and scope of development in Hout Bay}

Hout Bay is a spatially separate residential suburb of Cape Town offering a high-quality environment. Its mountain scenery, rural atmosphere and beautiful bay make it an area of high aesthetic quality (Oelofse \& Dodson, 1997). The different components of the mixeduse development assessed in this study included a residential complex, a commercial centre, a medical centre, an education facility, a petrol station and sporting facilities, including a riding school. For the purposes of this study, mixeduse development is defined as several developmental components which address different needs of the community within a specific location. Such a mixed-use development can include shopping, leisure, education, medical and other facilities.

The property earmarked for the development covers approximately 20 hectares. It was envisaged that 30 per cent of the land would be developed for commercial purposes and the remainder of the property could be used for recreation, sports and other activities. The community of Hout Bay can be divided into five geographical strata: Llandudno, the Harbour area, Imizamo Yethu, the Village and the Upper Valley. A graphic illustration of the survey area together with the survey strata is provided in Figure 1.

A brief profile of each stratum or subcommunity is provided below:

- Llandudno: A dormitory suburb of Hout Bay, situated away from the main town, with

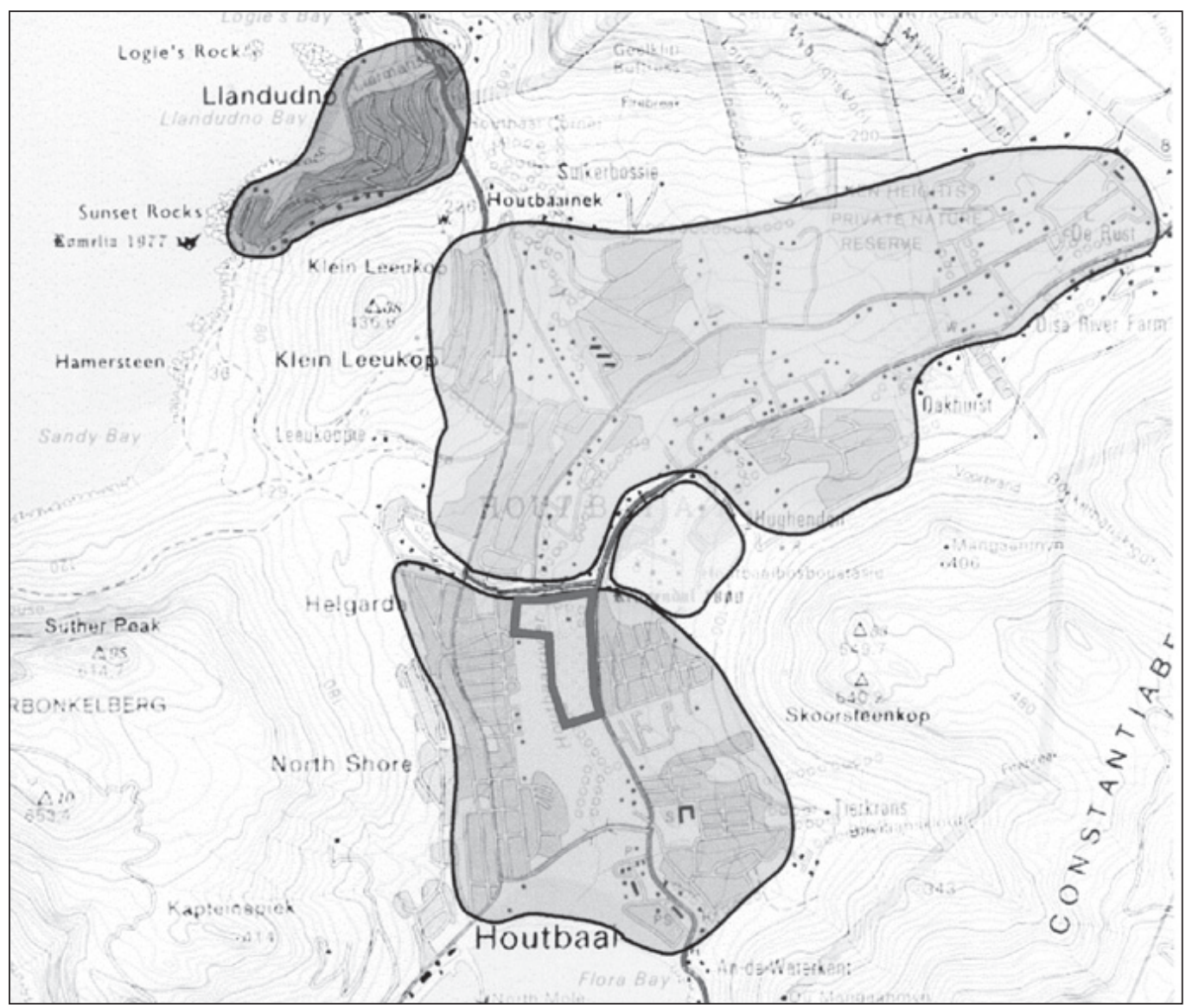


low levels of community facilities and services. The residential area comprises medium-density housing. The average resident has an upper- or middle-level socio-economic status.

- Harbour: The harbour area is characterised by high-density public housing. Most of the residents are coloureds, generally have a low socio-economic status, and are also involved in fishing. The harbour area itself also provides industrial and commercial activities such as fish shops, fishing boats and pleasure craft.

- Imizamo Yethu: This area is primarily an informal settlement. Residents are mostly black and have a low socio-economic standing. Only basic services are offered within the informal settlement.

- Village: This stratum has two parts. The village contains most of the town's commercial and civic activities. Most tourist facilities are also situated in the village area. The density of the buildings is relatively high. The central area is the most developed area, and comprises largely residential housing and some commercial activities. The make-up of the residential area is mainly medium- to high-density developments. This area is also surrounded by large open spaces.

- Upper Valley: This area contains mainly medium- and low-density residential development. There is a high concentration of smallholdings in this area and residents generally have a high socio-economic status. Some agricultural-related activity also occurs within the Upper Valley area.

\section{4}

\section{Research design and methodology}

A survey was conducted by a property developer among residents of Hout Bay in Cape Town in order to ascertain perceptions and attitudes towards mixed-use property development. The survey instrument was compiled with inputs from experts, and pre-tested among a selected group of residents to ensure that the questions were balanced and that an adequate reflection of responses was obtained.

\subsection{Population and sample}

The population was defined as all households that are permanent residents and/or own property in the magisterial district of Hout Bay. Residents from the informal settlement of Imizamo Yethu were also included in the population. The sample design was a stratified, systematic, random sampling procedure. A geographical basis was used for the identification of strata. The strata were defined using the expertise of town planners who are familiar with the geographical scope of the Hout Bay area. A sample size of 400 permanent residents or owners of property in Hout Bay was planned. The sample size represented 10.1 per cent of the net number of registered built erven. A total of 382 personal interviews were conducted among residents of the Hout Bay area. The five strata covered the entire magisterial district of Hout Bay. From the total of 4,422 registered properties in the area at the time, the sample was drawn to include responses of 7.55 per cent of Llandudno residents, 3.34 per cent of Harbour residents, 13.8 per cent of Imizamo Yethu residents, 47.75 per cent Village residents and 27.56 per cent Upper Valley residents.

\subsection{Statistical analysis}

The statistical analysis was conducted using Statistica (1998). Cronbach Alpha coefficients were computed to assess the internal consistency of the measuring instrument. Descriptive statistics (mean, median, standard deviation, skewness and kurtosis) were used to assess the variables considered for analysis and to highlight any significant departures from normality. An exploratory factor analysis was conducted, as no specified a priori restrictions were specified. The nature and scope of the statistical analysis were not determined prior to the research and therefore the findings are of an exploratory nature.

The 15 statements reflecting residents' perceptions and attitudes were considered for the purposes of a factor analysis. The formulated 
statements had a response continuum linked to a Likert scale of five points $(1=$ strongly disagree and $5=$ strongly agree). The assessment of the correlations and communalities for the 15 statements indicated that two variables were poorly correlated with the other statements and also exhibited small communalities and were therefore excluded from the analysis. The first part of the analysis entailed the calculation of a Cronbach Alpha for the 13 variables. A coefficient of 0.63 was obtained, which is somewhat low. Notwithstanding, the reliability of coefficients lower than 0.5 is deemed to be questionable, that of coefficients close to 0.70 as acceptable and that of coefficients of 0.80 as good (Sekaran, 1992: 174).

Together with a descriptive analysis of the statements, a correlation matrix and communalities were used to assess the appropriateness of using factor analysis as a technique to assess the interrelationships and explain the common underlying dimensions between the variables. In order to further confirm the relevance of exploratory factor analysis, the Keizer-Meyer-Olkin measure of sampling adequacy was calculated, which provides a measure of the extent to which the variables belong together and are thus appropriate for factor analysis. Kaiser and Rice (1974) provide the following calibration for the sampling adequacy measure: $0.90+$ is marvellous; $0.80+$ is meritorious; and $0.70+$ is middling. The sampling adequacy measure of 0.804 was obtained for the importance rating scores of the statements.

In order to assess the appropriate use of an extraction and rotation method, several options were considered based on the nature and scope of the statements and the objectives of the analysis. The Alpha and Principle Components methods were considered for extraction, while the Varimax Orthoganal and the Direct Quartimin oblique methods were used for rotation. The Varimax rotation method is the most widely accepted analytical method of rotation, and facilitates interpretation of factors by increasing their variance and thus their information content (Mitchell, 1994: 6). The oblique method of rotation allows for the factors to be not totally independent of each other, and some commonality is maintained. An oblique extraction is also favoured when latent variables are correlated, which results in improved estimates of the true factors and a simplified structure. However, Stewart (1981: 59) quotes from empirical evidence which suggests that most rotational methods tend to yield similar results for a given set of variables.

The Alpha method of extraction was used because the list of variables included in the analysis was not considered as comprehensive. This method is appropriate when a list of variables to be analysed can be assumed to be a sample from the universe of relevant variables (O’Neill \& Bhowan, 1997: 15). The Alpha extraction method was able to explain 50.11 per cent of the variance. The Principle Component method of extraction was used for comparative purposes, as it explains 64.38 per cent of the variance. Although the Principle Component method is technically less suitable for the purposes of this research, it is used to overcome the possibility that certain statements may also have been included if a priori knowledge of the research outcomes was available and known.

The number of factors extracted was based on the roots criterion, whereby only factors with eigenvalues larger than one are removed. The eigenvalue rationale is that each individual factor should account for at least the variance of a single variable if it is to be retained for interpretation. Mitchell (1994: 6) suggests that the eigenvalue approach is probably most reliable when the number of variables is between 20 and 50 . However, in this instance, the number of variables used in the analysis is less than 20 , which may result in the extraction of a conservative number of factors. Although this method has met with criticism, it is suitable for analysis that has fewer than 40 variables (in this case only 13 variables are being analysed) (Stewart, 1981: 58). It is not used as the sole extraction criterion for the analysis. The screetail test is also considered as an additional approach to identify the optimum number of factors that could be extracted (Cattell, 1966). However, a scree-test will result in at least one, and sometimes two or three more factors being considered more significant than will latent root 
criterion. A scree-test is derived by plotting the eigenvalues against the number of factors. The shape of the resulting curve is used to evaluate the cut-off point. Figure 2 is a representation of a scree plot of the factor eigenvalues obtained for the 13 statements included in the analysis.

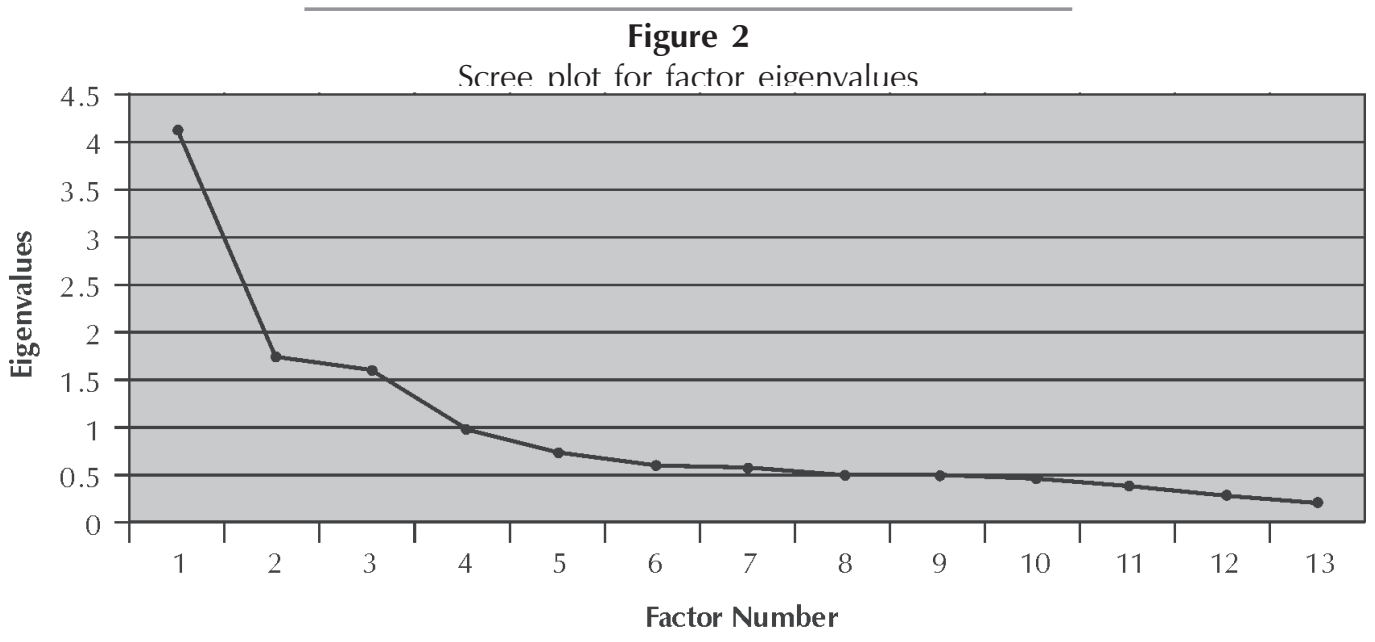

\subsection{Results and interpretation of selected findings}

The initial findings of the research suggest that the majority of respondents (77.66 per cent) agreed that the development of Hout Bay over the past three to five years has promoted the existing character of the area. They acknowledge the contribution of development to the growth and renewal of the area and agree with the stimulation of new growth nodes. However, the majority of respondents (62.47 per cent) did not support the development of Hout Bay as a place to live, work and participate in leisure activities.

The findings of the research also suggest that 34.88 per cent of respondents, who were supportive of Hout Bay being developed, also perceived the development of Hout Bay over the past three to five years as having promoted the existing character of the area. The majority of respondents (42.50 per cent) who were supportive of the development of Hout Bay, were also of the opinion that development over the past three to five years has not promoted the existing character of the Hout Bay area. Of the respondents who did not support the development of Hout Bay, 19.62 per cent were also of the opinion that developments of the area over the past three to five years did not promote the existing character of the area.

Furthermore, the findings of the statistical analysis suggest that significant differences occur between the support of respondents for development of Hout Bay and development promotes the character of the Hout Bay area at the 1 per cent significance level. The Pearson and Yates chi-square tests indicated statistically significant differences at the 1 per cent significance level. The Yates correction is a more refined method applicable to two-by-two cross-tabulations.

\subsubsection{Descriptive analysis of the findings}

A descriptive analysis of the 13 statements was conducted as part of an exploratory approach to the analysis of the data. Several statistics of central tendency and dispersion, together with statistics that could assist with the clarification of the distribution, were calculated. The findings are presented in Table 1. 
Table 1

Descriptive statistics of variables included in the analysis

\begin{tabular}{|c|c|c|c|c|c|c|}
\hline Statement & $\mathbf{N}$ & Mean & Median & Standard deviation & Skewness & Kurtosis \\
\hline 1 & 379 & 2.551451 & 2 & 1.305003 & 0.17047 & -1.43077 \\
\hline 2 & 374 & 3.131016 & 4 & 1.120824 & -0.6394 & -0.88763 \\
\hline 3 & 378 & 3.507937 & 4 & 1.0358 & -0.93555 & -0.05788 \\
\hline 4 & 380 & 4.197368 & 4 & 0.963992 & -1.38117 & 1.57137 \\
\hline 5 & 380 & 4.097368 & 4 & 1.044394 & -1.17377 & 0.63014 \\
\hline 6 & 326 & 3.208589 & 4 & 1.194624 & -0.60506 & -0.83295 \\
\hline 7 & 382 & 2.58377 & 2 & 1.350434 & 0.14588 & -1.49251 \\
\hline 8 & 375 & 3.722667 & 4 & 1.175914 & -0.82614 & -0.36018 \\
\hline 9 & 372 & 4.002688 & 4 & 1.052525 & -1.0931 & 0.47566 \\
\hline 10 & 372 & 3.239247 & 4 & 1.139474 & -0.58951 & -0.61248 \\
\hline 11 & 321 & 3.588785 & 4 & 1.139791 & -1.04236 & 0.20859 \\
\hline 12 & 319 & 3.467085 & 4 & 1.235487 & -0.82504 & -0.31213 \\
\hline 13 & 318 & 2.842767 & 3 & 1.245988 & -0.15201 & -1.28853 \\
\hline
\end{tabular}

Legend for statements:

1. Development of vacant land enhances the character of the area.

2. Property development promotes growth and renewal of the area.

3. Development of vacant land contributes towards economic growth and job creation in the area.

4. Property development places an additional demand on the existing infrastructure of the area.

5. Property development often involves undesired construction activity (dust, noise, construction vehicles, etc.).

6. Nature and scope of the building should be vernacular in design and blend with the architecture of other buildings in the surrounding area.

7. Development of vacant land in the area should be encouraged.

8. Property development should only be allowed in specified areas.

9. Only property development that blends with the existing character of the area should be permitted.
10. Development of vacant land should be used to stimulate new community growth nodes in the area.

11. Land should be developed that is central and in close proximity to other existing developments.

12. Developments with a mixed-use character that are in the public interest should be accessible to all residents.

13. Proximity to the harbour, beach and key residential areas are key to decision-making when considering the development of vacant land in the area.

The mean and median were used as measures to describe the perceptions of respondents. The mean scores suggest that respondents generally disagreed that development of vacant land enhances the character of the Hout Bay area, and that development of vacant land should be encouraged. However, they agreed that property development places an additional demand on the existing infrastructure of the area, that it can result in undesired construction activity, and that only property development that blends in with the existing character of the area should be permitted. Further perusal of the mean 
scores for the remaining statements suggests that respondents were unsure and could not agree or disagree. An assessment of the other descriptive statistics suggests that no major deviations from normality were apparent among the responses to the statements.

\subsubsection{Factor analysis}

The results of the factor analysis for each of the extraction and rotation methods are presented in Table 2. Factor loading scores of less than 0.4 were ignored.

\section{Table 2}

Factor loading scores for the Varimax and Direct Oblimin rotation applicable to the extraction methods

\begin{tabular}{|c|c|c|c|c|}
\hline Variable & $\begin{array}{l}\text { Alpha } \\
\text { Varimax } \\
\text { rotation }\end{array}$ & $\begin{array}{l}\text { Alpha } \\
\text { direct } \\
\text { Oblimin } \\
\text { rotation }\end{array}$ & $\begin{array}{c}\text { Principal } \\
\text { component } \\
\text { Varimax } \\
\text { rotation }\end{array}$ & $\begin{array}{c}\text { Principal } \\
\text { component } \\
\text { Oblimin } \\
\text { rotation }\end{array}$ \\
\hline \multicolumn{5}{|l|}{ Factor 1 Macro perspective } \\
\hline Variance explained by factor (\%) & $(27.30)$ & $(27.30)$ & $(21.21)$ & $(21.21)$ \\
\hline $\begin{array}{l}\text { Development of vacant land enhances character of } \\
\text { the area }\end{array}$ & 0.663 & 0.632 & 0.708 & 0.684 \\
\hline $\begin{array}{l}\text { Property development promotes growth and } \\
\text { renewal of the area }\end{array}$ & 0.757 & 0.801 & 0.806 & 0.827 \\
\hline $\begin{array}{l}\text { Development of vacant land contributes towards } \\
\text { economic growth and job creation in the area }\end{array}$ & 0.533 & 0.570 & 0.712 & 0.759 \\
\hline $\begin{array}{l}\text { Development of vacant land in the area should } \\
\text { be encouraged }\end{array}$ & 0.715 & 0.699 & 0.753 & 0.734 \\
\hline $\begin{array}{l}\text { Development of vacant land should be used to } \\
\text { stimulate new growth nodes in the area }\end{array}$ & 0.496 & 0.461 & 0.604 & 0.578 \\
\hline \multicolumn{5}{|l|}{ Factor 2 Micro perspective } \\
\hline Variance explained by factor (\%) & $(10.03)$ & $(10.03)$ & $(18.77)$ & $(18.77)$ \\
\hline $\begin{array}{l}\text { Land should be developed that is central and in } \\
\text { close proximity to other existing developments }\end{array}$ & 0.683 & 0.704 & 0.798 & 0.818 \\
\hline $\begin{array}{l}\text { Developments with a mixed-use character that are in } \\
\text { the public interest should be accessible to all residents }\end{array}$ & 0.812 & 0.860 & 0.841 & 0.866 \\
\hline $\begin{array}{l}\text { Nature and scope of the building should be vernacular } \\
\text { in design and blend with the architecture of other } \\
\text { buildings in the surrounding area }\end{array}$ & 0.511 & 0.513 & 0.669 & 0.681 \\
\hline $\begin{array}{l}\text { Proximity to the harbour, beach and key residential } \\
\text { areas are key to decision-making when considering } \\
\text { the development of vacant land in the area }\end{array}$ & 0.631 & 0.598 & 0.686 & 0.660 \\
\hline \multicolumn{5}{|l|}{ Factor 3 Area-specific factors } \\
\hline Variance explained by factor (\%) & $(8.75)$ & $(8.75)$ & $(12.49)$ & $(12.49)$ \\
\hline $\begin{array}{l}\text { Property development should only be allowed in } \\
\text { specific areas }\end{array}$ & 0.568 & 0.567 & 0.816 & 0.819 \\
\hline $\begin{array}{l}\text { Only property development that blends in with the } \\
\text { existing character of the area should be permitted }\end{array}$ & 0.866 & 0.880 & 0.864 & 0.868 \\
\hline
\end{tabular}




\begin{tabular}{|c|c|c|c|c|}
\hline Factor 4 Infrastructure and superstructure & & & & \\
\hline Variance explained by factor (\%) & $(4.04)$ & $(4.04)$ & $(11.92)$ & $(11.92)$ \\
\hline $\begin{array}{l}\text { Property development places an additional demand } \\
\text { on the existing infrastructure of the area }\end{array}$ & 0.430 & 0.431 & 0.779 & 0.796 \\
\hline $\begin{array}{l}\text { Property development often involves undesired } \\
\text { construction activity (dust, noise, construction } \\
\text { vehicles, etc.) }\end{array}$ & 0.754 & 0.786 & 0.787 & 0.782 \\
\hline $\begin{array}{l}\text { Keizer-Meyer-Olkin measure of sampling } \\
\text { adequacy (KMO) Total \% of variance explained }\end{array}$ & 0.80450 .11 & 0.80450 .11 & 0.80464 .38 & 0.80464 .38 \\
\hline
\end{tabular}

The findings of the exploratory factor analysis presented in Table 2 indicate that the 13 statements could be reduced to four factors. The authors have labelled each factor for descriptive purposes.

Factor 1 represents what may be termed a macro perspective, which indicates that development can enhance the character of the area, promotes renewal and contributes towards economic growth and job creation in the area; that it can be used to stimulate new growth nodes; and that development of vacant land should be encouraged. Factor 2 may be considered as a micro perspective, and suggests that development should be central, in close proximity to the harbour, beach and key residential areas; developments should be accessible to all residents if in the public interest; and the buildings envisaged for the property should be vernacular in design, and fit in with the surrounding architecture. The third factor relates to location-specific factors of the coastal enclave, which indicates that property development should only be permitted in designated areas, and development should blend in with the existing character of the area. The fourth factor relates to infrastructure and superstructure, and highlights the additional demand development places on the existing infrastructure, and the occurrence of undesired construction activity that may result while the development takes place.

\subsubsection{Differences in perceptions of different socio-economic groupings}

The community of Hout Bay was divided into five sub-groups (strata), namely Harbour, Imizamo Yethu, Village, Upper Valley and
Llandudno. Perusal of the stratification map (see section 3) indicates that spatially, Llandudno forms a separate substratum and the residents are geographically removed from the business district of Hout Bay. Due to the geographical separation of Llandudno, it was assumed that residents would not experience the full impact of the mixed-use development to the same extent when compared to the other four community groupings. The responses of respondents living in the Llandudno stratum were therefore not included in the analysis.

After examining the mean responses of the four remaining groups to each of the statements, and whether or not differences between the four groups were statistically significant, it was decided to consolidate the groups on the basis of socio-economic characteristics. The outcome of the analysis provided two primary groups for further analysis.

Respondents residing in the Harbour and Imizamo Yethu areas were pooled together as Group 1. In order to justify the pooling of these resident groups, the statistical significance of differences between the mean responses of the two groups was determined for each of the statements. The findings suggest that no statistically significant differences occurred among the groups in 10 , or 76.92 per cent, of the 13 statements. However, the three statements that indicated statistically significant differences between the two groups are as follows:

- Property development should only be allowed in specified areas $(\mathrm{p}=0.0066)$

- Development of vacant land should be used to stimulate new growth nodes in the area $(\mathrm{p}=0.0033)$ 
- Developments with a mixed-use character that are in the public interest should be accessible to all residents $(\mathrm{p}=0.0088)$.

Despite these differences, residents of the two groups agree with more than 76 per cent of the statements. However, it is possible that some statements may have been misinterpreted due to the language barrier of English or Afrikaans among Imizamo Yethu residents. The responses of the communities in the Village and Upper Valley were also pooled. No significant differences occurred between the responses of the two groups for all 13 statements at the 5 per cent significance level. The different perceptions of Group 1 (Harbour and Imizamo Yethu residents) and Group 2 (Village and Valley residents) regarding the four key factors listed in section 4.3.2 are presented in Table 3.

Table 3

Differences in perceptions of groups of residents regarding four factors

\begin{tabular}{|c|c|c|c|}
\hline Variable & $\begin{array}{c}\text { Group } 1 \\
\text { mean }\end{array}$ & $\begin{array}{l}\text { Group } 2 \\
\text { mean }\end{array}$ & P-value \\
\hline \multicolumn{4}{|l|}{ Factor 1 Macro perspective } \\
\hline Development of vacant land enhances character of the area & 3.77 & 2.05 & $0.000 *$ \\
\hline $\begin{array}{l}\text { Property development promotes growth and renewal of } \\
\text { the area }\end{array}$ & 3.89 & 2.83 & $0.000^{*}$ \\
\hline $\begin{array}{l}\text { Development of vacant land contributes towards economic } \\
\text { growth and job-creation in the area }\end{array}$ & 3.84 & 3.37 & $0.001^{*}$ \\
\hline Development of vacant land in the area should be encouraged & 3.78 & 2.10 & $0.000^{*}$ \\
\hline $\begin{array}{l}\text { Development of vacant land should be used to stimulate new } \\
\text { growth nodes in the area }\end{array}$ & 3.83 & 3.00 & $0.000^{*}$ \\
\hline \multicolumn{4}{|l|}{ Factor 2 Micro perspective } \\
\hline $\begin{array}{l}\text { Land should be developed that is central and in close } \\
\text { proximity to other existing developments }\end{array}$ & 3.53 & 3.11 & $0.007^{*}$ \\
\hline $\begin{array}{l}\text { Developments with a mixed-use character that are in the } \\
\text { public interest should be accessible to all residents }\end{array}$ & 3.83 & 3.520 & $0.043^{* *}$ \\
\hline $\begin{array}{l}\text { Nature and scope of the building should be vernacular in } \\
\text { design and blend with the architecture of other buildings } \\
\text { in the surrounding area }\end{array}$ & 3.69 & 3.40 & 0.084 \\
\hline $\begin{array}{l}\text { Proximity to the harbour, beach and key residential areas are } \\
\text { key to decision-making when considering the development } \\
\text { of vacant land in the area. }\end{array}$ & 3.62 & 2.62 & $0.000^{*}$ \\
\hline \multicolumn{4}{|l|}{ Factor 3 Area-specific factors } \\
\hline Property development should only be allowed in specific areas & 2.75 & 4.12 & $0.000^{*}$ \\
\hline $\begin{array}{l}\text { Only property development that blends in with the existing } \\
\text { character of the area should be permitted }\end{array}$ & 3.24 & 4.31 & $0.000^{*}$ \\
\hline \multicolumn{4}{|l|}{ Factor 4 Infrastructure and superstructure } \\
\hline $\begin{array}{l}\text { Property development places an additional demand on the } \\
\text { existing infrastructure of the area }\end{array}$ & 3.74 & 4.38 & $0.000^{*}$ \\
\hline $\begin{array}{l}\text { Property development often involves undesired construction } \\
\text { activity (dust, noise, construction vehicles, etc.) }\end{array}$ & 3.56 & 4.31 & $0.000^{*}$ \\
\hline
\end{tabular}

Note ${ }^{*} \mathrm{p}<0,01 ;{ }^{* *} \mathrm{p}<0,05$; Group 1 - Harbour and Imizamo Yethu; Group 2 - Village and Valley 
It is interesting to note that no significant difference occurred in the responses of the two groups regarding buildings that should be vernacular in design and blend in with the architecture of other buildings in the surrounding area, at the 5 per cent significance level. This finding suggests that if development is allowed, clear architectural guidelines should be developed and diligently applied to any building activity planned for the Hout Bay area.

In terms of the macro perspective, Group 1 is generally more positive regarding development than Group 2. Group 1 agrees that development of vacant land enhances the character of the area, promotes growth and renewal and that development of vacant land in the area should be encouraged. Group 2, on the other hand, is more likely to resist development, since they disagree to a greater extent with the three statements above. Even though statistically significant differences exist between the groups at the 1 per cent significance level, the average perceptions among communities pooled as Group 1 are significantly more positive regarding development than the combined residents of the Village and Upper Valley (Group 2).

Significant differences at the 5 per cent significance level also exist between the average responses of the two groups related to the micro perspective. The proximity of a new development to existing developments, the harbour, beach and key residential areas and that development should be in the public interest indicates a higher level of agreement on average among residents of Group 1 than Group 2.

Group 2 expressed strong and differing views regarding area-specific factors when compared to Group 1. For example, that property development should only be allowed in specific areas and that it should blend in with the existing character of the area. It appears that Group 2 will only support development that meets certain conditions. Significant differences at the 1 per cent significance level exist between the average perceptions of Groups 1 and 2 with regard to how development should take place in the area.
The two groups also differ significantly in terms of aspects related to infrastructure and superstructure. Group 2 expressed strong views that property development places an additional demand on the existing infrastructure of the area $($ mean $=4.38)$ and that it involves undesired construction activity $($ mean $=4.31)$. The average responses of Group 1 suggest that they tend to be more neutral than agreeing with the mean response view of Group $2(p=0.000)$.

\section{5 \\ Discussion of the findings}

Respondents were generally supportive of the development of Hout Bay as a place to live, work and participate in leisure activity. They acknowledge the contribution of development towards the growth and renewal of the area and agree with the stimulation of new growth nodes. Respondents are generally opposed to the argument that developments in Hout Bay over the past three to five years have contributed towards the character and tranquillity of the area. Respondents are apparently apprehensive about future developments (53 per cent disagree/strongly disagree).

The statements used for measuring the perceptions of residents towards development could be grouped into four main factors. The authors labelled these factors as macro, micro, area-specific, and infrastructure and superstructure factors. Statements that pertain to the macro factor described development in broad terms, highlighting the economic benefits and environmental impact of development on the community. Micro factors referred to how development will possibly change the patterns of social interaction and impact the lives of respondents. Statements that grouped together under this factor focused on the issue of proximity and accessibility of residents to the development considered in this research. Furthermore, future development should reflect the existing architecture of the area. Areaspecific factors refer to the unique character of the area and that property development should blend in with the existing character of the area and only be permitted in specified areas. 
Statements that refer to infrastructure and superstructure suggest that development places additional demand on existing infrastructure and can lead to undesired construction activity.

The community of Hout Bay were divided into two main groups. Group 1 covered the communities of lower socio-economic status, i.e. Imizamo Yethu and residents who live in the Harbour area. Group 2 included the middleand upper socio-economic residents residing in the Village and Upper Valley. Statistically significant differences at the 5 per cent significance level were recorded for 12 of the 13 statements. The residents from Imizamo Yethu and the Harbour were on average more supportive of development from a macro and micro perspective. The residents of the Village and Upper Valley, on the other hand, expressed strong views concerning the necessity to control development (an area-specific factor), that it caused undesired construction activity and placed additional demand on the infrastructure of the area.

The reasons for these responses can possibly be explained by the differences in socioeconomic status of the two groups. The residents of Imizamo Yethu and the Harbour area appear more supportive of development, as they perceive that development will lead to job creation and increased economic benefits. As unemployment is a problem in these areas, these groups would benefit directly from any form of direct investment. The residents of the Village and Upper Valley are more affluent and concerned with maintaining their current status and wealth standing. They do not perceive development to be beneficial, and therefore perceive any direct investment in superstructure as a threat to the tranquillity and beautiful surroundings of Hout Bay and the areas in which they live.

6

\section{Further research}

The research presented in this paper offers several avenues for further research, which have both practical relevance and create additional research opportunities for academics:
- The list of statements used in the research could be increased to include other aspects of development. A greater focus could be placed on aspects related to the sociocultural and infrastructure and superstructure impacts. The broader regional impact of the development was not considered in this research and would provide some indication of the geographical and other spatial consequences.

- As a development has macro, meso (market) and micro impacts on a given area, an analysis of perceptions of development could be extended to include other stakeholders such as business, investors and property developers, as well as public sector institutions such as local municipalities, provincial and national government.

- A much broader research project could focus on developing guidelines and metrics related to a development. The current research could be used to develop qualitative guidelines, which could be used in conjunction with a range of quantitative metrics to assess the impact of development prior to and after the development has been operational for some time. For instance, the statement: "Property development promotes growth and renewal of the area" could be associated with measurements related to the level of revenue of surrounding businesses, the number of businesses locating to, or leaving the area, and the net increase in direct and indirect permanent employment in the area with specific reference to development. These metrics can then be compared to the perceptions of residents to determine the validity of perceptions held.

7

\section{Conclusion}

The purpose of this study was to determine the perceptions and attitudes of residents (the local community) towards a mixed-use development in Hout Bay, Cape Town. Aspects addressed in 
the paper were whether or not the perceptions and attitudes of residents regarding urban development could be reduced to several key factors, and whether or not community groups with different socio-economic backgrounds differ with regard to their views concerning development.

Resident perceptions were reduced to four key factors. These factors refer to a macro perspective, micro perspective, area-specific, and infrastructure and superstructure impacts. The perceptions of two combined groups with differing socio-economic backgrounds, i.e. Imizamo Yethu and the Harbour area residents and residents from the middle- to upper-income areas of the Village and Upper Valley, were assessed. The perceptions of these groups differed significantly for all the statements at the 5 per cent significance level. Residents from the lower-income areas were more optimistic about further development than middle- and upper-income residents from the Upper Valley and Village. These differences may be attributed to the perceived benefits associated with the job opportunities that would be generated by a new development. More affluent residents are more concerned with maintaining their current status and wealth standing. They do not perceive development to be highly beneficial, but rather consider it as jeopardising the tranquillity and beautiful surroundings of Hout Bay.

Although the study had certain limitations (e.g. the nature and scope of the questions covered in the survey had to form the basis for the analysis), the research could be expanded upon to further analyse the social and community engagement aspects related to development. It is also clear that property developers need to understand the community's perceptions and attitudes towards development and engage their input from the planning stages. Due to the limited research on community perceptions and attitudes towards property development in the South African context, the findings may contribute to furthering the debate on issues related to social engagement, property access and community benefits and associated costs from a socio-economic perspective.

\section{Endnote}

We would like to express our gratitude to the property developer for providing the data to conduct the research presented in this article. The usual caveat applies.

\section{References}

1 ALZUBAIDI, H.; VIGNALI, C; DAVIES, B.J. \& SCHMIDT, R.A. (1997) "Town-centre versus out-of-town shopping: A consumer perspective”, International Journal of Retail \& Distribution Management, 25(2): 78-89.

2 AMIT-COHEN, I. (forthcoming) "Synergy between urban planning, conservation of the cultural built heritage and functional changes in the old urban centre: The case of Tel Aviv", Land-Use Policy, Article in press.

3 ARNOLD, S.J. \& LUTHRA, M.N. (2000) "Market entry effects of large format retailers: A stakeholder analysis", International Journal of Retail \& Distribution Management, 28(4/5): 13954.

4 BOWEN, R.E. \& RILEY, C. (2003) "Socioeconomic indicators and integrated coastal management", Ocean \& Coastal Management, 46, Article in press.

5 BRAMMER, R. \& TOMASIK, J. (1995) "Retail potential analysis for local economic developers", Economic Development Review, (Spring 1995): 32-42.

6 BROMLEY, R.D.F. \& THOMAS, C.J. (1993) Retail Change: Contemporary Issues, UCL Press: London.

7 CAllegARI, F. \& VAlleGA, A. (2002) "Coastal cultural heritage: a management tool" Journal of Cultural Heritage, 3(2002): 227-36.

8 CATTELL, R.B. (1966) "The Scree-Test for the number of factors", Multivariate Behavioural Research, 1(April): 245-76.

9 COASTAL FUTURES 2025 (2000) Town Meeting on America's Coastal Future: Using the internet to promote coastal stewardship. Available: http://oceanservice.noaa.gov/websites/ retiredsites/natdia_pdf/sum_results.pdf.

10 CORGEL, J.B.; LING, D.C. \& SMITH, C.S. (2001) Real Estate Perspectives: An Introduction to Real Estate (4 ${ }^{\text {th }}$ ed.) McGraw-Hill Irwin: Boston.

11 FIFE, I. (2003) "Friction in paradise: Golf estate home owners cry foul over leisure development plans", Financial Mail, (28/02): 62. 
12 GREEN, R. (1999) "Meaning and form in community perception of town character", Journal of Environmental Psychology, 19: 31129.

13 GUBB, A. (2003) "Graft and the environment Roodefontein”, Mail \& Guardian, April, 3, Available: http://www.wcape.school.za/wessa.

14 GUY, C.M. (1996) "Official publications on retail development: A review article”, Planning Practice \& Research, 11(2): 227-31.

15 HALLSWORTH, A.G. \& JOHNSON, R.B. (2001) "The perceived impact of an off-centre factory outlet mall: The local community dimension", International Journal of Retail \& Distribution Management, 29(10): 462-71.

16 HO, R.P.K. (1997) "Hong Kong people's 'subjective feelings' about pollution”, Environmental Management and Health, 8(3): 94-9.

17 IRCHA, M.C. (1982) "Shopping centres: Their development and impact in Atlantic Canada", Plan Canada, 22(4): 35-44.

18 JONES, P. \& HILLIER, D. (2002) "Multileisure complexes", International Journal of Retail \& Distribution Management, 30(9): 42530.

19 KALTENBORN, B.P. (1998) "Effects of sense of place on responses to environmental impacts: A study among residents in Svalbard in the Norwegian high Arctic", Applied Geography, 18(2): 169-89.

20 KAISER, H.F. \& RICE, J. (1974) "Little Jiffy Mark IV", Educational \& Psychological Measurement, 34 (Spring): 111-7.

21 MANZO, L.C. (2003) "Beyond house and haven: Toward revisioning of emotional relationships with places", Journal of Environmental Psychology, 23: 47-61.

22 MBEKI, T. (2003) "Characteristics of South Africa's first and third world economies", $A N C$ Today, Letter from the president, 28/08/03. Available: http://www.sarpn.org.za/documents/ d0000830/index.php.

23 MBEKI, T. (2003) "The second economy, what it is and what is needed to meet the growth and development challenges it presents", Address by President T. Mbeki to the National Council of Provinces 11/11/03.

Available: http://www.sarpn.org.za/documents/ d0000830/index.php.

24 MITCHELL, V.W. (1994) "How to identify psychographic segments", Marketing Intelligence \& Planning, 12(7): 410.
25 MOKHTAR, M.B.; AZIZ, S. \& AZIZ, A.G. (2003) "Integrated coastal zone management using the ecosystems approach, some perspectives in Malaysia", Ocean \& Coastal Management, Article in Press.

26 O'NEILL, C. \& BHOWAN, K. (1997) "Determinants for changes to entrepreneurship courses at selected South African universities.", Management Dynamics, 6(3): 1-23.

27 O'NEIL, A.E. \& DELMERICO, J. (1995) "Analyzing retail potential in rural communities: The Georgia Tech handbook", Economic Development Review, 13(2): 87-9.

28 O'REGAN, B.; MOLES, R.; KELLY, R.; RAVETZ, J. \& MCEVOY, D. (2002) "Developing indicators for the estimation of sustainable settlement size in Ireland", Environmental Management and Health, 13(5): 450-66.

29 OELOFSE, C. \& DODSON, B. (1997) "Community, place and transformation: A perceptual analysis of residents' responses to an informal settlement in Hout Bay, South Africa”, Geoforum, 28(1): 91-101.

30 PARSA, A.R.G. \& FARSHCHI, M.A. (1996) "Environmental regulations and the real estate industry", Property Management, 14(1): 6-23.

31 PERRINGS, C. \& ANSUATEGI, A. (2000) "Sustainability, growth and development", Journal of Economic Studies, 27(1/2): 19-54.

32 PILLAY, U. \& DU TOIT, J. (2004) "Urban renewal unit to round up experts for cities", HSRC review, 2(1): March 2004.

33 SEKARAN, U. (1992) Research Methods for Business: A Skill Building Approach (2 ${ }^{\text {nd }}$ ed.) John Wiley: New York.

34 SHILliNG, J.D. (2002) Real Estate (13 ${ }^{\text {th }}$ ed.) South-Western: Thomson Learning: Australia.

35 SIMONS, P.L. (1991) "Retail development: Assessing economic impacts quickly", International Review of Retail, Distribution \& Consumer Research, 1(3): 353-66.

36 STATSOFT (1998). Statistica. Version 5.5. Tulsa, OK.

37 STEWART, D.W. (1981) "The application and misapplication of factor analysis in marketing research", Journal of Marketing Research, 18(1): 51-62.

38 TAUSSIK, J. (1999) "The contribution of spoilt land to the sustainable development of the coast", Marine Pollution Bulletin, 38(9): 752-9.

39 VANCE, S.S. \& SCOTT, R.V. (1994) Wal-Mart: A History of Sam Walton's Retail Phenomenon, Twayne Publishers, New York, NY. 